\title{
A KOLLEKTIVITÁS HAGYOMÁNYOS ÉS ALTERNATÍV ÉRTELMEZÉSEI - EGY 40 ÉVES KUTATÁS MAI TANULSÁGAI
}

\section{F. Lassú Zsuzsa}

Eötvös Loránd Tudományegyetem

A kollektivitás, a közösségi viszonyulás társadalmi és pedagógiai kérdései ma éppoly fontosak, ha nem fontosabbak, mint 40 évvel ezelőtt. Globalizálódott világunk egyszerre ad teret az individuum elmagányosodásának és megszünésének, a totális közösségi létformáknak, ahol az egyén minden gondolata a megszületés pillanatában megosztásra kerül. Ez a közösségi lét azonban nem feltétlenül jelent egy igazi közösséghez való tartozást, ahol az egy mindenkiért, mindenki egyért kölcsönös felelössége és gondoskodása a jellemző. Mai közösségeink sokkal inkább a szabadidő eltöltésének, a közös érdeklődés kifejeződésének és a gondolatok artikulálódásának színterei, s csak kevéssé van jelen bennük az együtt munkálkodás jóleső fáradtsága, a közös célok által vezérelt tevékenység sikerének öröme, vagy éppen a kudarc közösen megélt csalódása.

Jelen írásomban mégis egy olyan közösségértelmezést szeretnék középpontba állítani, amely 40 év távlatából is fontos értéktartalmakkal bír. Az 1971/72-es tanévben Hunyady Györgyné kandidátusi kutatómunkája részeként az iskolai közösséghez való viszonyulást, a gyermekek közösségi helyzetét és ennek hatásait vizsgálta. A nagyszabású, módszertanilag is sokoldalú kutatás 50 iskolai osztályt, 1332 gyermeket vizsgált, bevonva azok pedagógusait is (Hunyadyné, 1977). Dolgozatomban ennek a kutatásnak néhány fontos elemét emelem ki, hogy általuk új nézőpontok és értelmezési keretek felhasználásával megvizsgáljam azokat a fogalmakat, amelyek a közösséghez való viszonyulás értelmezésében előtérbe kerülnek.

\section{A kollektivitás fogalma}

A kollektivitás a közösséghez való viszonyulást jelenti. A kifejezés a kollektíva, közösség szóból származik, melynek jelentését a Magyar értelmező kéziszótár a következőképpen határozza meg: közös élet- vagy munkaviszonyok között élő, illetve közös eszmék, célok által egyesített emberek csoportja (Magyar értelmező kéziszótár, 2003). A közösséget (Gemeinschaft) Tönnies, német szociológus azáltal különbözteti meg a társadalomtól (Gesellschaft), hogy az előbbit valóságos és szerves társas viszonylatként tételezi, míg utóbbit ideális és mechanikus képződménynek. A közösség, elmélete szerint, olyan kölcsönös igenléssel jellemezhető viszony, mely ,egységet hoz létre a sokaságban, vagy sokaságot az egységben” (Tönnies, 2004).

A kölcsönös egymásrautaltság és közös célok által meghatározott, egységes és mégis sokszínü közösség definíciója tehát lényegében rokon értelmü a csoport szociálpszichológiai meghatározásával (ld. pl. Smith, Mackie, 2004), noha mindannyian érezzük, hogy valamiképpen több annál. Ezt a többletet nehéz megragadni, leginkább értékeket hordozó mivoltát szokták hangsúlyozni, így 
maga a közösség szó is pozitív tartalmú, míg a csoport önmagában sokkal inkább semleges, értékmentes. Ezt az értéktöbbletet Pataki Ferenc is hangsúlyozza a társadalmi csoportokról szólva: „A csoport fogalmát elvileg kétfajta társadalmi képződményre alkalmazzuk. Ezzel az elnevezéssel illetjük először is a közvetlen személyes kölcsönhatáson és együttműködésen alapuló és ekképpen müködö, viszonylag nem nagy létszámú, többé-kevésbé tartós társas alakzatokat, személyközi (interperszonális) együtteseket. Ezeket szokás társadalmi kiscsoportoknak vagy (amennyiben értékszempontot vezetünk be elemzéseinkbe) kollektíváknak nevezni." (Pataki, 1977, 160.) A közösséghez való viszony tehát immanensen magában hordoz egy pozitív tartalmat, az, aki pozitívan viszonyul a közösséghez, ezáltal pozitív értékkel ruházódik fel, noha mindannyian tudjuk, hogy léteznek olyan közösségek, amelyek céljával és eszközeivel a társadalom többsége nem azonosul, azokat megveti, elutasítja.

A dilemma felismerése mellett mégis megmaradok a pozitív megközelítésnél, és a közösséget mint értéket hordozó társadalmi képződményt veszem alapul, így a közösséghez való pozitív viszonyt mint elérendő, pedagógiailag támogatandó célt tekintem.

A kollektivitás számos pszichológiai nézőpontból, többféle pszichológiai fogalmat segítségül hívva értelmezhető. Jelen tanulmányban, a teljesség igénye nélkül tárgyalom a pszichológiai alapkutatások néhány szubjektíven kiragadott, a témával összefüggésbe hozható megközelítését.

\section{A kollektivitás megközelítései}

A szociálpszichológia témakörein belül a kollektivitás felfogható szociális attitüdként, ahogyan elsősorban Hunyady Györgyné is tette, ám kutatásai eredményeinek értelmezésében egyéb megközelítések is megjelenhetnek. Az elöbb említett pozitív értéktartalom és pedagógiai célok elővételezik a kollektivitás érték-pszichológiai értelmezését, ám a kutatásban részt vevő, különböző életkorú gyermekek válaszainak összevetésekor természetesen felmerülnek a fejlődéslélektan vonatkozó elméletei is, például az én fejlődésére vagy az erkölcsi fejlödésre vonatkozóan. A kérdés kutatásában segítségül hívhatjuk emellett az általános és a személyiség-lélektan fogalmait is. A kutatásban fontos kérdés a közösséghez tartozás, a közösségért való tevékenykedés motívumainak vizsgálata, így a motivációra vonatkozó pszichológiai nézőpontok mindenképpen segíthetnek az értelmezésben. Emellett felmerülhet a közösséghez való viszonyulás és a szociabilitás mint személyiségvonás összefüggése is.

Mindezek a fogalmak azonban maguk is kulturálisan meghatározott reprezentációk, értelmezésük nem független a kortól és a társadalomtól, melyben születnek. Nem megkerülhető ezért a téma tárgyalásakor az indvidualizmuskollektivizmus kulturális dimenziójának megragadása sem. 


\section{A közösségi viszonyulás mint attitüd}

A közösségi viszonyulás felfogható attitüdként, és így három komponense vizsgálható (ld. pl. McGuire, 2001). Kognitív összetevője tartalmazza a közösségi érdekek, célok, normák, hagyományok ismeretét, valamint a közösségért érzett tudatos felelősséget, amely értelmezhető egyfajta morális tudatként is. Mindezek az egyén fejében lévő tudattartalmak sohasem sterilen, hanem az affektív komponenssel együttmüködve, az által befolyásolva hozzák létre a közösség fejünkben lévő mentális reprezentációját. Az érzelmi komponens a tudáselemeket átszínezi, reakcióinkban megelőzi, testileg, zsigerileg is kifejezve a közösséghez való ragaszkodást vagy az attól való elzárkózást (Zajonc, 2003). Mindez megnyilvánul az örömben, ha együtt vagyunk, a csalódásban, ha nem sikerülnek közös céljaink, a kirekesztettségtől való félelemben, a más közösségektől való viszolygásban, a közösségtől való eltiltásra reagáló haragban vagy a közösség felbomlásakor érzett bánatban. A közösségi viszonyulás viselkedéses komponense mindazokban a tevékenységekben érhető tetten, melyeket az érzelmi és gondolati indíttatás nyomán az egyén tesz - a közösségért való cselekvésekben, illetve az ezekre való készenlétben.

\section{Kognitív tényező - felelősségtudat}

A közösségi érdek tudatos felismerése, a közösségért való felelősségvállalás Hunyady Györgyné kutatásainak egy fontos eleme. A közösségért való felelősség felismerése, a „közöm van hozzá”, „részem van benne”, „felelős vagyok érte” felismerések tudatosulása a kollektív tevékenységek fontos motívuma. A közösségért érzett felelösség azonban nem elözheti meg az egyéni élettér feletti felelősség tudatosulását. A gyermek először annak lesz tudatában, hogy felelős saját testéért, saját cselekedeteiért, majd értelmi-érzelmi és szociális fejlődésével párhuzamosan egyre inkább felismeri felelösségét családja, barátai és tágabb környezete, például iskolai osztálya életében. Csak serdülökorban tudatosul azonban az ország, a kultúra, Európa vagy az egész Föld iránti felelősségünk (Szabó, Kékesi, 2012; Krzywosz-Rynkiewicz, Zalewska, 2009). A Hunyadyné által feltárt eredmény, amely az általa vizsgált felső tagozatos gyerekek életkorral növekvő egyre tudatosabb, túlzásoktól egyre inkább mentes közösségi viszonyulását mutatta, ezért értelmezhető a felelősség táguló körében.

\section{Érzelmi tényező - a közösséghez való kötődés}

A közösséghez való érzelmi viszonyulás a szociális attitüd legmeghatározóbb eleme. A pozitív érzelmi viszony felfogható mint egyfajta kötődés, kapocs természetesen nem a kötődés fejlődéslélektani értelmében, de annak jelentéséből fontos elemeket (pl. ragaszkodás, öröm, biztonság élménye) megtartva.

Az iskolához való kötődés érzését, vagyis az iskola iránti pozitív attitüdöt iránya alapján két összetevőre bonthatjuk: az első magára az iskolára vonatkozik, vagyis azokat az érzéseket (pl. büszkeség, odatartozás, biztonság) tartalmazza, melyek az iskolához mint intézményhez kapcsolódnak, a második pedig a személyekhez füződik, akik a gyermek iskolai életében részt vesznek (Hirschi, 
1969). Hazai vizsgálatban Szabó Éva és Virányi Barbara (2011) az iskolai kötődés mértékével szorosan összefüggő tényezőnek találták a tanulmányi eredményt és a magatartást - az erősen kötődő gyermekek gyengén kötődő társaiknál gyakrabban voltak mindkét szempontból „dicséretesek”.

Az iskolához való viszony ugyanakkor erősen összefügg az iskolai, közösségi életbe való bevonódással, vagyis a szociális attitüd viselkedési komponensével.

\section{Viselkedési tényező - bevonódás a közösségi tevékenységekbe}

Nem meglepő módon a bevonódás a közösségi tevékenységekbe szorosan összefügg a szociális viszonyulás attitűd-skálán mért erősségével, vagyis azok, akik fontosabbaknak tartják a közösségi érdekeket, nagyobb arányban vesznek részt a közösségi, a közösségért végzett tevékenységekben (Hunyadyné, 1977).

Ugyanakkor az sem meglepő, hogy a közösség életében aktívabb közösségi tisztségviselők pozitívabb attitüddel rendelkeznek a közösség iránt. Ezt az összefüggést Hunyadyné 1971-1972-ben végzett kutatásai éppúgy bizonyították, mint Szabó Éva és Virányi Barbara 2011-es vizsgálata, vagyis nem csak egy kor, egy ideológia megnyilvánulására, hanem általános igazságra lelhetünk: aki szereti, az teszi. Vagy aki teszi, az szereti? Tyúk vagy tojás kérdésre bukkanunk, ami nem új felvetés az attitüd és attribúció pszichológia kutatásának történetében, mióta Bem felvetette: „szeretem a barna kenyeret, mivel rendszeresen eszem” (Bem, 1972).

A közösségi bevonódásnak azonban nemcsak a közösség szempontjából vannak előnyei. Hunyadyné 40 évvel ezelőtti kutatásai és újabb nemzetközi kutatások is arra az eredményre jutottak, hogy a pozitív közösségi attitüd, és a nagyobb mértékü iskolai bevonódás jobb tanulmányi eredménnyel, kevesebb magatartási problémával jár együtt (Hawkins, Weis, 1985; McBride et al., 1995).

Összefoglalva elmondhatjuk, hogy a kollektivitás szociális attitüdként való értelmezése a téma vizsgálatának mindmáig fontos, ha nem a legmeghatározóbb megközelítése.

\section{A közösségi viszonyulás mint személyes és egyben kulturális érték}

A kollektivizmus az egyén által preferált értékként is felfogható, így értelmezését megkönnyítheti, ha egy értékmodellben elhelyezve vizsgáljuk.

Schwartz (1992) szerint az értékek vágyott célok, melyek fontossága egyénenként változó lehet, egymáshoz való viszonyuk hierarchikus, az egyén vagy csoport életelvének meghatározói, motiválják a cselekvést, normaként funkcionálnak, és a szocializáció során sajátíthatók el. Az általa univerzálisnak leírt 10 motivációs érték egymással támogató vagy versengő kapcsolatban lehet, hasonló jellemzőik alapján összetartoznak vagy szemben állnak, ezáltal jól definiálható értékstruktúrát hoznak létre. Az egymással szomszédos értékek, közös jellemzőik alapján, nagyobb szerkezeti egységekbe összevonhatók. Ezáltal Schwartz végül 2 fö dimenziót tárt fel, melyet empirikus vizsgálatai is igazoltak. Az első dimenzió a változásra való nyitottság, szemben a megőrzéssel. A második 
dimenzió az én-hangsúlyozás, szemben az én-transzcendenciával, amely szembeállítja az egyén saját sikerének és dominanciájának hangsúlyozását a másik személyt egyenlőként elfogadó és az annak jólétével való törődést hangsúlyozó értékekkel. A közösségi viszonyulás is itt, az én-transzcendencia dimenziójában helyezhető el.

A személyes értékek szocializációja ugyanakkor az adott kultúrában történik, amely maga is értékként tekint bizonyos célokra, motívumokra. Hofstede és munkatársai kultúrközi összehasonlító kutatásai alapján Magyarország individualista irányultságú ország, így az egyének fontosabbaknak tartják az egyéni, mint a közösségi célokat, érdekeket (Hofstede és Hofstede, 2008). A Hunyadyné által, a hetvenes években kapott eredmények, melyek az általános és középiskolások közösségi viszonyulásában egy kisiskolás korban már pozitív attitűd életkorral előrehaladó tudatosulását mutatták, valószínüleg nagyban köszönhetők voltak egy társadalmi-politikai berendezkedés ideáljának. Valószínűsíthető, bár erre nézve nincsenek konkrét adataink, hogy az azóta eltelt időben végbement, ismert értékrendváltozás a közösségi viszonyulás mint érték háttérbe szorulását eredményezte a gyermekek körében is. Ezért nagyon fontos pedagógiai cél a pozitív közösségi viszonyulás támogatása, fejlesztése, céltudatos tanítása.

\section{A kollektivitás én-pszichológiai értelmezése}

A kollektivitás értelmezhető az én-pszichológia fogalmi körében is. Az én fejlődésével kapcsolatos nyugati tudományos elméletek egyetértenek abban, hogy az én-élmény kialakulásának fontos összetevője az én és a nem én elkülönülése, melyet Mahler a szeparáció-individuáció folyamatában ír le (Mahler, Pine, Bergman, 1975). Szerinte a gyermek, egy rövid ingerbarrier, az ún. normál autizmus fázisa után, kezdetben önmagát az anyával egynek éli meg, ez a duálunió állapota, melyet az ön-indította tevékenységek nyomán kialakuló saját test élmény és az anya mint különálló lény megélése szakít meg, és amely folyamat a szeparáción keresztül vezet az egyénné válás, az individuáció irányába.

A szeparáció élménye ugyanakkor felfogható egyfajta hiányt keltő élményként, melynek hatására kialakul a ragaszkodó magatartás és a kötődés, amely minden társas kapcsolatunk alapja (Bowlby, 2009). A közösségi viszonyulás, a közösségbe való vágyódás ezáltal az individuáció folyamatának következményeként is értelmezhető, s mint ilyen, függ annak jellemzőitől.

Az individuáció elkülönülést, elszakadást jelent az anyától, amely annál kifejezettebb, minél inkább képes a gyermek önmagát az anyától különbözőnek megélni. A feminista pszichoanalitikus, Jean Baker Miller (1987) szerint ez az individuáció sokkal kifejezettebb a fiúgyermekek esetén, akik nemi különbözőségük okán könnyebben alakítanak ki önálló, elkülönült szelfet, míg a lányok az anyával való fokozott azonosulás következtében sosem individualizálódnak teljesen, hanem ún. beágyazott, kapcsolati selfet hoznak létre. Ez a kapcsolati self a kapcsolatokban való önmeghatározást, a kapcsolatokra való nagyobb igényt, ezáltal erősebb közösségi viszonyulást hoz létre a nőkben, mint a 
férfiakban (ld. pl. Blazina, 2004). Miller elméletét a modern kötődéskutatások csakúgy megerősítették, mint Hunyadyné, aki szintén a lányok magasabb szociális attitűdjét találta vizsgálatában, noha a kultúrközi összehasonlító vizsgálatok eredményei arra is felhívják a figyelmet, hogy ez a különbség nem egyetemes, és nem független a társadalom jellemzöitöl (ld. pl. Schmitt et al, 2003.)

\section{A közösségi tevékenységek motívuma és összefüggése az erkölcsi fejlödéssel}

A közösségért való tevékenységek motivációja megközelíthető egyrészt a motiváció általános elméleteit felhasználva. Ekkor alapvető szembenállásként jelenhet meg a külső-belső, intrtinzik-extrinzik motiváció elkülönítése, amely felfogható egy folytonos dimenzió két végpontjaként, amely dimenzión számos más pont is megfogható, és így az is megtörténhet, hogy bizonyos körülmények között az extrinzik motiváció belsővé válik (ld. Ryan, Connel Deci, 1985).

Hunyadyné vizsgálatában egy sportpályaépítés történetét elmesélve arra kérte a gyermekeket, hogy rangsorolják a különböző közremüködő gyerekek motivációit, mennyire tetszett nekik az adott gyermek indoklása a részvételre vonatkozóan. A felkínált indokok 4 fokozatban írták le a közösségi tevékenység motivációit, melyek a külső jutalommal vezérelt egyéni érdektől a belülről jutalmazott közösségi érdek felé haladva jelentenek különböző fejlettségi, illetve pedagógiailag kívánatos szinteket. Az eredményekből kitünik, hogy 1972-ben a vizsgált felső tagozatos gyerekek több mint $50 \%$-a a belülröl motivált egyéni érdeket önmagához közelebb érezte, mint a közösségi érdeket. Az egyéni érdek ugyanakkor csak a belső motiváció esetében tetszett a gyermekeknek, a megkérdezettek mindössze 3\%-a rangsorolta első helyre a kívülről motivált és egyéni érdekből tevékenykedő tanuló indoklását. A belső motiváció egyértelmű előnyét mutatja a kutatás, hiszen a gyermekek kevesebb mint 10\%-a rangsorolta első helyre a kívülröl motivált, jobb jegyért vagy győzelemért tevékenykedő gyermekek indoklását. Azaz az indoklás vonzerejét nem az egyéni vagy közösségi érdek kérdése, hanem a motiváció helye befolyásolta erősebben. A belülről motivált tett, irányuljon egyéni vagy közösségi célra, mindenképpen vonzóbb a felső tagozatos gyermekek számára, mint a kívülről motivált cselekedetek. Az eredményeket a modern motivációkutatás is megerősíti, bár a Hunyadyné által használt négy motivációs szintet más értelemben használják (ld. Decy és Ryan, 1985).

Ugyan a vizsgálat nem irányult a 10 évesnél fiatalabb korosztályra, azonban más kutatásokból (ld. pl. Deci és Ryan fent említett munkáját) tudjuk, hogy a belsőleg vezérelt motívumok aránya az életkor előrehaladásával nő. Ennek számos magyarázata közül most az erkölcsi fejlődéssel való összefüggést emelem ki.

Piaget és Kohlberg kognitív fejlődéslélektani elméleteikben egyaránt azt feltételezték, hogy a gyermek helyes, erkölcsös viselkedése kezdetben csak külső kényszer vagy jutalmazás reményében van jelen. Piaget ezt a fázist nevezte heteronóm erkölcsiségnek, melyet csak 8-10 éves korban kezd az idegrendszeri érés és szocializáció hatására felváltani az autonóm szabálykövetés szakasza, ahol 
a gyermek már képes belátni, magáévá tenni a szabály értelmét, ezáltal belülről motivált annak betartására (Piaget, 1970).

Kohlberg (1997) kutatásai alapján részletesebb szakaszfelosztást hozott létre, amelyben a prekonvencionális szakasz lényegében megfelel a heteronóm erkölcsiségnek, azonban a belülről irányított erkölcs szakasza nem egységes. A fejlődéssel a serdülő és a felnőtt egyre inkább képes a konvenciókat egyénileg értelmezni, és ebben a posztkonveniconális szakaszban már nem az elfogadás, a beilleszkedés motiválja a közösségi cselekedetet, hanem a belülröl választott egyéni erkölcsi meggyőződés, amely akár arra is motiválhatja az egyént, hogy az általa megvetett közösség céljait ne kövesse, annak tevékenységeiben ne vegyen részt. Ez az erkölcsiség legmagasabb szintje, amely bizonyos esetekben az elnyomó csoportoknak való behódolás megtagadásával, a morálisan elutasított csoportokból való tudatos távolmaradással jár.

A tudatosság ilyenfajta növekedését Hunyadyné is feltárta kutatásában, amikor az életkor növekedésével a közösségre vonatkozó túlzó kijelentések egyre növekvő elutasítását találta.

\section{A szociális attitűd összefüggése a szociabilitással}

A szociabilitás a személyiség vonásaként is felfogható, s mint ilyen, alapvető veleszületett temperamentum-jellemző (Thomas, Chess, Birch, 1968). Már a legkisebb csecsemök is különböznek abban, hogy mennyire keresik a másikkal való szoros kapcsolatot, vagy igénylik mások társaságát. Vannak szociálisan nyitott, kezdeményező gyerekek és vannak visszahúzódók, félénkek. A nyitott gyerekek sokkal több interakciót kezdeményeznek és bátrabban lépnek be a társas helyzetekbe, ezáltal fejlődésük során sokkal több lehetőségük adódik társas kompetenciák kialakítására és gyakorlására (Sanson, Hemphill, Smart, 2004).

A félénk gyerekeknek ehhez sokkal több támogatásra, kedvezőbb szocializációs tapasztalatokra van szükségük, és mivel a szociabilitás öröklöttsége folytán nagy eséllyel szüleik szintén visszahúzódók, így sokan közülük a közösségbe lépve magukon hordozzák a születéskor öröklött félénkség jegyeit.

A szociabilitás a csoportbeli társas pozíció fontos meghatározója - a fejlett társas kompetenciákkal rendelkező gyerekek elfogadottabbak, gyakrabban lesznek a csoport vezetői, jobban bevonódnak a közösség életébe.

\section{Zárszó}

Az itt felvázolt nézőpontok a teljesség igénye nélkül járták körül egy remek kutatás ma is aktuális kérdéseit. Hunyady Györgyné a közösség és a társas kapcsolatok pedagógiai szempontú kutatásának fontos kérdéseit tárgyalja sok remek írásában, melyek közül most csak egyet, a hozzám legközelebb állót vettem górcső alá, hogy alapvető fogalmát, a kollektivitást szubjektíven kiragadott szempontjaim alapján új nézőpontokba helyezve tárgyaljam. A nézőpontok áttekintése után most itt lenne az idő, hogy valamilyen összefoglalással zárjam elöadásomat, de a mindenki által hazavihetö örök tanulság helyett, én kérdésekkel zárom szavaimat. 
A szociális viszonyulás tárgyalásakor számomra felvetődő első kérdés, hogy honnan ered? Vannak-e öröklött elemei, és mely összetevőit tanuljuk?

Amennyiben tanulható, akkor hol tanuljuk leginkább? A családban eldöl minden, vagy az iskolának és a pedagógusoknak még vannak esélyei arra, hogy tervezett módon, a nevelés tudatos eszközeivel fejlesszék ezt a viszonyulást? És ha igen, mennyire lehet ebben a családokra támaszkodni, őket ebbe a folyamatba bevonni?

És számomra a legfontosabb kérdés, hogy hogyan lehet egyén és közösség érdekét összebékíteni, alapvetően individualista társadalmunkban a gyermekeket arra nevelni, hogy másokért éppannyira érezzenek felelősséget, mint saját magukért, hogy belső indíttatásból tevékenyen vegyenek részt a közösség életében?

Ezek a kérdések ma még sokkal inkább aktuálisak, mint 40 évvel ezelött voltak, s ma itt a sok kiváló pedagógust és kutatót látva bízom benne, hogy még sokunkat motiválnak kiváló kollektív és egyéni erőfeszítésekre.

\section{Jegyzetek}

Bem, D. J. (1972). Self-Perception Theory. In L. Berkowitz (Ed.), Advances in Experimental Social Psychology (Vol. 6, pp.1-62). New York: Academic Press.

Blazina, C. (2004). Gender role conflict and the dis-identification process: Two case studies on fragile masculine self. The Journal of Men's Studies, 12, 151-161.

Bowlby, J. (2009): A biztos bázis. Animula Kiadó, Budapest.

Deci, E. L., \& Ryan, R. M. (1985). Intrinsic motivation and self-determinaton in human behaviour. New York: Plenum.

Hawkins, J. D. and Weis, J. G. (1985). The social development model: an integrated approach to delinquency prevention. Journal of Primary Prevention, 6, 73-97.

Hirschi, T. (1969). Causes of Delinquency. Berkeley: University of California Press.

Hofstede G., Hofstede, G. J. (2008): Kultúrák és szervezetek. Az elme szoftvere. VHE Kft., Pécs.

Hunyady Györgyné (1977): Kollektivitás az iskolai osztályokban. A közösségi beállitódás strukturális meghatározói. Akadémiai Kiadó, Budapest.

Kohlberg, L. (1997): Az igazságosságra vonatkozó ítéletek hat szakasza. In Bernáth László - Solymosi Katalin (szerk.): Fejlödéslélektan: olvasókönyv. Tertia, Budapest.

Krzywosz-Rynkiewicz, B. \& Zalewska, A. M. (2009). Citizens of the Future: How young people perceive social problems from both local and global perspectives, In Ross, A. (ed) Human Rights and Citizenship Education. London: CiCe, pp 383-391.

Mahler, M.; Pine, F.; Bergman, A. (1975). The Psychological Birth of the Human Infant. New York: Basic Books.

McBride, C. M., Curry, S. J, Cheadle, A., Anderman, C., Wagner, E. H., Diehr, P. and Psaty, B. (1995). School-level application of a social bonding model to adolescent risk-taking behavior. Journal of School Health, 65(2), 63-68.

McGuire, W. J. (2001): Az egyedi attitüdök és attitüdrendszerek struktúrája. In: McGuire, W. J.: Makacs nézetek és a meggyözés dinamikája. Osiris Kiadó, Budapest.

Miller, J. B. (1987). Toward a new psychology of women (2nd ed.). Boston: Beacon Press. 
Pataki Ferenc (1977): A társadalmi „nagycsoportok” értékorientációi. In: Pataki Ferenc: Társadalomlélektan és társadalmi valóság. Kossuth könyvkiadó, Budapest. 158-188. Piaget, J. (1970): Válogatott tanulmányok. Gondolat Kiadó, Budapest.

Ryan, R. M., Connell, J. P. \& Deci, E. L. (1985). A motivational analysis of selfdetermination and self-regulation in education. In C. Ames \& R. E. Ames (Eds), Research on motivation in education: The classroom milieu (pp. 13-51). New York: Academic Press.

Sanson, A., Hemphill, S. A., Smart, D. (2004). Connections between temperament and social development: a review. Social Development, 13, 1.

Schmitt, D. P. et al. (2003). Are men universally more dismissing than women? Gender differences in romantic attachment across 62 cultural regions. Personal Relationships, $10,307-331$.

Schwartz, S. H. (1992). Universals in the Content and Structure of Values: Theory and Empirical Tests in 20 Countries. In M. Zanna (ed.), Advances in Experimental Social Psychology (Vol. 25). New York: Academic Press: 1-65.

Smith, E. R. \& Mackie, D. M. (2004): Szociálpszichológia. Osiris Kiadó, Budapest.

Szabó Éva - Kékesi Márk (2012): A felelösség koncentrikus szerkezete. Az egyéni felelösségtudat mintázatai magyar középiskolások és egyetemisták körében. Előadás a Magyar Pszichológiai Társaság XXI. Tudományos Nagygyülésén, Szombathely, 2012. május 30-június 1.

Szabó Éva - Virányi Barbara (2011): Az iskolai kötődés jelentősége és vizsgálata. Magyar Pedagógia, 111. évf. 2. szám, 111-125.

Thomas, Chess \& Birch (1968). Temperament and Behavior Disorders in Children. New York: New York University Press.

Tönnies, F. (2004): Közösség és társadalom. Gondolat Kiadó, Budapest.

Zajonc, R. (2003): Az érzelem és megismerés kapcsolata. In: Zajonc, R.: Érzelmek a társas kapcsolatokban és a megismerésben. Osiris Kiadó, Budapest. 279-335. 